\title{
Pemanfaatan Media Visual Pada Pembelajaran IPS Di MI Darul Mutaallimin Sidoarjo
}

\author{
Taseman $^{1}$ \\ ${ }^{1}$ Prodi PGMI IAI Al Khoziny Buduran Sidoarjo, Indonesia \\ Email: tasemanpgmi@gmail.com
}

\begin{abstract}
Abstrak
Penelitian ini dilakukan untuk mengetahui manfaat media visual pada pembelajaran IPS di Madrasah Ibtidaiyah.Metode yang digunakan dalam penelitian ini adalah metode deskriptif kualitatif.Jenis penelitian yang dipilih menggunakan data kualitatif.Pengumpulan data menggunakan dua teknik yakni, observasi dan wawancara.

Berdasarkan hasil penelitian diketahui bahwa 1) Terdapat perbedaan kecepatan pemahaman antara kelas yang menggunakan dan tidak menggunakan media pembelajaran berbasis visual, 2) Dengan adanya media visual ini, siswa lebih aktif dan antusias dalam mengikuti pembelajaran 3) Kendala-kendala dalam pembuatan media visual ini adalah keterbatasan waktu, biaya dan faktor usia.

Oleh karena itu, pendidik harus lebih kreatif dalam mengembangkan media visual pada pembelajaran IPS sehingga dapat memudahkan proses pembelajaran.
\end{abstract}

Kata Kunci : Pemanfaatan, Pembelajaran IPS, Media Visual 


\section{PENDAHULUAN}

Di zaman sekarang kualitas dan mutu pendidikan dasar dituntut untuk menjadi lebih baik lagi, dikarenakan kualitas pendidikan di Indonesia yang belum bisa menghasilkan secara optimal SDM yang mampu bersaing. Mindset masyarakat dalam proses belajar banyak diartikan bahwa belajar itu identik dengan buku dan menulis, sehingga dengan pemikiran tersebut secara tidak langsung dapat mematikan kreatifitas guru atau pengajar dalam mengeksplorasi sistem pengajaran yang efektif dan dinamis. Dalam mengembangkan system pengajaran yang efektif dan dinamis, guru atau pengajar dapat membuat atau menggunakan media pembelajaran.

Pemanfaatan media pembelajaran merupakan permasalahan yang sering kita jumpai dalam proses belajar mengajar di sekolah dasar, khususnya dalam pembelajaran IPS. Kebanyakan media yang digunakan hanya buku paket dan papan tulis.Buku paket pun digunakan oleh peserta didik hanya apabila guru atau pendidik menyuruh untuk membacanya atau mengerjakan soal-soal yang ada.

Menurut Muhammad Rahmatullahbahwasanya Ilmu Pengetahuan Sosial (IPS) merupakan mata pelajaran yang mempelajari kehidupan sosial dengan melibatkan permasalahan sehari-hari masyarakat sekitar yang didasarkan pada kajian geografi, ekonomi, sosiologi, sejarah, antropologi, ilmu politik, dan sebagainya ${ }^{1}$. Puskur dalam Muhammad Rahmatullahmengungkapkan bahwa pembelajaran IPS bertujuan untuk mengembangkan kemampuan peserta didik dalam rasa peka terhadap masalah sosial yang terjadi di masyarakat sekitar, menghadapi perbaikan segala ketimpangan yang terjadi dengan sikap mental yang positif, dan mengatasi setiap masalah yang terjadi sehari-hari dengan trampil, baik yang menimpa dirinya sendiri maupun masyarakat.

Pendidikan IPS di SD/MI merupakan bentuk perwujudan dari disiplin berbagai ilmu sosial, sehingga mata pelajaran IPS bukanlah mata pelajaran dengan disiplin ilmu tunggal melainkan gabungan dari berbagai ilmu, yakni bahan kajian geografi, ekonomi, sosiologi, antropologi, tatanegara, dan sejarah. Kajian

${ }^{1}$ Rahmatullah, Muhammad. 2011. Pengaruh Pemanfaatan Media Pembelajaran Film Animasi Terhadap Hasil Belajar (Studi Eksperimen pada Mata Pelajaran IPS Siswa Kelas VII SMPN 66 Banjarmasin). Edisi Khusus No. 1: 180 
tersebut berasal dari dimensi-dimensi pengajaran IPS yang meliputi empat dimensi, yaitu dimensi personal, sosial, waktu dan tempat ${ }^{2}$.Untuk itu, mata pelajaran IPS di MI sangatlah penting diberikan agar siswa memiliki rasa peka terhadap lingkungan di sekitar.

Rumampak dalam Ahmad Susantomengartikan bahwa media pembelajaran merupakan alat yang digunakan untuk memindahkan informasi dari satu orang ke orang lainnya ${ }^{3}$.Selain itu Barden dan Bryddalam Ahmad Susantomendefinisikam bahwa media pembelajaran sebagai alat yang menyediakan fungsi-fungsi pembelajaran yang dapat mengantarkan sebuah informasi ke peserta didik dengan tujuan untuk memfasilitasi dan dapat meningkatkan kualitas peserta $\operatorname{didik}^{4}$.

Brown et aldalam Ahmad Susantojuga mendefinisikan bahwa media pembelajaran digunakan sebagai teknologi dalam proses belajar mengajar yang dirancang dengan sistematis mulai dari perancangan, penggunaan, maupun evaluasi dari keseluruhan proses pembelajaran. Yang kemudian dikombinasikan dengan berbagai sumber daya manusia dan non manusia.Dari beberapa paparan diatas dapat disimpulkan bahwa media pembelajaran merupakan alat bantu yang digunakan dalam proses belajar mengajar yang bertujuan untuk memudahkan komunikasi antara guru dengan siswa maupun siswa dengan siswa yang lain, sehingga proses belajar mengajar dapat berlangsung dengan baik dan efektif.Dalam Cepi Riyana media pembelajaran ini mempunyai dua unsur penting dengan tujuan agar dapat lebih mudah menyajikan pesan, akan tetapi yang lebih penting dari kedua unsur itu yaitu pesan atau informasi belajar yang dibawakan oleh media. Dua unsur penting yang dimaksud adalah unsur peralatan atau perangkat keras (hardware) dan pesan yang dibawa (software) ${ }^{5}$.

\footnotetext{
${ }^{2}$ Fadli, Muhibuddin. 2015. Pengembangan Media Pembelajaran Berbasis Video Kelas IV Sekolah Dasar.Jurnal Dimensi Pendidikan dan Pembelajaran Vol 3. No. 1: 27

${ }^{3}$ Susanto ahmad, Pengembangan Pembelajaran IPS di Sekolah Dasar, (Jakarta : Prenada Media Group, 2014),hal, : 313

${ }^{4}$ Ibid,hal,313

${ }^{5}$ Riyana cepi, Media Pembelajaran, (Jakarta : Direktorat Jendral Pendidikan Islam KEMENAG RI, 2012), 10
} 
Menurut Djamarahdalam Indah mengemukakan kehadiran media mempunyai arti yang cukup penting dalam proses belajar mengajar. Hal ini dikarenakan media dapat menjadi perantara pesan yang menjelaskan ketidakjelasan bahan yang disampaikan. Kerumitan pembelajaran juga akan disederhanakan dengan hadirnya media. Media pun juga menyempurnakan ucapan guru yang kurang dalam penjelasan pembelajaran. Dengan demikian, peserta didik akan lebih mudah mencerna bahan daripada tanpa bantuan media. Disini nilai praktis media terlihat, yang bermanfaat bagi siswa dan guru dalam proses belajar mengajar ${ }^{6}$.

Media pembelajaran adalah alat bantu yang digunakan oleh seorang guru untuk menyampaikan materi pembelajaran sehingga mencapai tujuan dari pembelajaran tersebut. Iwan Falahudinberpendapat bahwa dalam kegiatan pembelajaran kita harus menentukan media yang akan digunakan, memilih media yang terbaik untuk tujuan pembelajaran bukanlah pekerjaan yang mudah. Pemilihan itu rumit dan sulit, karena harus mempertimbangkan berbagai factor, yakni Model pemilihan media dan Alasan pemilihan media ${ }^{7}$.Ada beberapa model pemilihan dalam memilih media pembelajaran, yaitu model pemilihan tertutup dan model pemilihan model terbuka.Pemilihan tertutup artinya media sudah didetapkan dari sebuah bahan ajar yng kira pakai misalnya yang tercantum dalam buku ajar.Sedangkan model pemilihan terbukaartinya, seorang guru masih bebas memilih jenis media yang sesuai dengan kebutuhan.

Media adalah alat yang digunakan untuk penunjang keberhasilan suatu pembelajaran. Sebagai salah satu penunjang keberhasilan pembelajaran maka media hendaknya harus sesuai dengan proses pembelajaran. Pemilihan media yang tepat sangat berpengaruh, karena pemilihan media yang tepat dapat menimbulkan interaksi yang kuat antara pengajar dan peserta didik.

Pemilihan media itu perlu kita lakukan agar dapat menentukan media yang terbaik, tepat dan sesuai dengan kebutuhan dan kondisi peserta didik.Maka, dalam pemilihan media harus dilakukan dengan baik sesuai keutuhan sekaligus

\footnotetext{
${ }^{6}$ Ainiya, Indah Ayu. 2014. Pemanfaatan Media Audio Visual Sebagai Sumber Pembelajaran Sejarah. Indonesian Journal of History education, Vol. 3 (1): 41-42

${ }^{7}$ Iwan Falahudin. 2014. Pemanfatan media dalam pembelajaran. 1(4): 104-117
} 
memperhatikan kriterianya. Karena dalam media pembelajaran terdapat kebelihan dan kekurangan.Dalam memilih media pembelajaran ada beberapa pertimbangan atau kriteria yang dapat digunakan agar tercapainya tujuan pembelajaran. Kriteria umum yang diperlukan diantaranya: Tujuan pembelajaran, Kesesuaian dengan materi, Karakteristik siswa, Gaya belajar siswa, Lingkungan, Ketersediaan fasilitas pendukung ${ }^{8}$. Menurut Anas mainan bahwa dalam pemilihan media pembelajaran harus memperhatikan tujuan yang ingin dicapai, Ketepatgunaan, Keadaan peserta didik, Ketersediaan, Mutu teknis (operasional), dan Biaya9.

Wina dalam Indahmengemukakan bahwa media bukan hanya merupakan alat bantu atau bahan saja, akan tetapi hal-hal yang dapat membantu siswa memperoleh pengetahuan. Menurut Ger-lach mediaa terdiri dari orang, bahan peralatan, atau kegiatan yang dapat membangun pengetahuan serta daya kreatifitas peserta didik bertambah. Media merupakan perantara seperti TV, radio, slide, bahan cetakan, tetapi meliputi orang atau manusia sebagai sumber belajar atau berupa kegiatan meliputi diskusi, seminar, karyawisata, simulasi dan lain sebagainya yang dikondisikan untuk menambah pengetahuan dan wawasan, mengubah sikap siswa untuk menambah pengetahuan ${ }^{10}$.

Media pembelajaran berbasis visual banyak digunakan di Madrasah Ibtidaiyah.Menurut Sukiman media pembelajaran berbasis visual adalah media pembelajaran yang menyalurkan pesan melalui indra penglihatan ${ }^{11}$. Sedangkan menurut Arsyadmedia visual adalah suatu bentuk menyeluruh yang dapat dikenal (dilihat) yang dapat membantu pemahaman pesan atau informasi yang dikandungnya.Sehingga dari uraian diatas dapat disimpulkan bahwa media pembelajaran berbasis visual adalah media belajar yang menyampaikan pesan atau materi pembelajaran melalui penglihatan siswa atau sebuah media yang

\footnotetext{
${ }^{8}$ Jalinus, Nizwardi, dan Ambiyar. Media dan Sumber Pembelajaran. (Jakarta: Prena Media Group, 2016), hal,18

${ }^{9}$ Anas, Muhammad. Alat Peraga dan Media Pembelajaran, (Jakarta: 2011),hal,7

${ }^{10}$ Ainiya, Indah Ayu. 2014. Pemanfaatan Media Audio Visual Sebagai Sumber Pembelajaran Sejarah. Indonesian Journal of History education, Vol. 3 (1): 41-42

${ }^{11}$ Sukiman. Pengembangan Media Pembelajaran. (Yogyakarta: Pedagog, 2012), hal, 85
} 
hanya dapat dilihat oleh siswa.Media visual terdiri atas media yang dapat diproyeksikan dan media yang tidak dapat diproyeksikan ${ }^{12}$.

Pada intinya, media visual yang diproyeksikan adalah sebuah media yang menggunakan alat proyeksi sehingga gambar atau tulisan tampak pada layar.Media ini dapat berbentuk media proyeksi diam seperti gambar diam (still pictures) dan media proyeksi gerak, seperti gambar bergerak (motion pictures) Perkembangan dunia media visual saat ini sudah berkembang sangat pesat. Sehingga saat ini kegiatan pembelajaran di beberapa sekolah sudah menggunakan media bantu alat proyeksi LCD dengan berbantuan komputer. Pada sekolah yang memiliki kemampuan untuk menggunakan alat proyeksi LCD, tentunya bisa mengatur kegiatan pembelajaran dengan lebih menarik, karena bisa menampilkan berbagai hal yang terkait dengan pencapaian kompetensi atau tujuan pembelajaran jika dibanding dengan alat proyeksi lainnya.

Sedangkan, media visual yang tidak diproyeksikan (Non Projected Visual) diantaranya: gambar fotografik dan media grafis. Gambar fotografik atau seperti fotografik termasuk dalam gambar diam (still pictures), contohnya gambar tentang manusia, binatang, tempat atau objek lainnya yang berkaitan dengan materi pembelajaran yang disampaikan kepada siswa. Sedangkan media grafis merupakan suatu penyajian secara visual yang menggunakan titik-titik, garisgaris, gambar-gambar, tulisan atau simbol visual yang lain dengan maksud untuk menggambarkan dan merangkum suatu ide, data atau kejadian. Ada beberapa jenis media grafis yang biasanya dipakai dalam proses pembelajaran di sekolah yakni diantaranya sketsa, gambar, grafik, bagan, poster, karikatur, dan peta.

Levie \& Lents (dalam Arsyad, 2013:20) mengemukakan empat fungsi media pembelajaran, khususnya media visual, yaitu: 1) Fungsi atensi media visual merupakan fungsi inti yakni menarik dan mengarahkan perhatian siswa untuk berkonsentrasi kepada materi pelajaran, 2) Fungsi afektif media visual bisa dilihat dari tingkat kenikmatan siswa ketika belajar (atau membaca) teks yang bergambar, 3) fungsi kognitif dari media visual dapat terlihat pengungkapan dari

\footnotetext{
${ }^{12}$ Arsyad, Azhar. Media Pembelajaran. (Jakarta: Rajagrafindo Persada.2013),hal,108
} 
para ahli bahwa lambang visual atau gambar dapat memperlancar kemampuan peserrta didik dalam menerima rangsangan materi., dan 4) sebagai fasilitas media pembelajaran dapat dilihat dari hasil penelitian, karena media berbasis visual membantu anak yang memiliki tinggat kemampuan rendah akan dapat mengikuti pembelajaran dengan baik ${ }^{13}$.

Dari beberapa paparan diatas kita dapat menyadari bahwa betapa pentingnya media pembelajaran dalam proses kegiatan belajar mengajar. Kita sebagai guru dan calon guru dituntut untuk membuat kegiatan pembelajaran itu lebih berkreasi, tidak monoton sehingga membuat peserta didik nyaman pada saat proses pembelajaran juga dapat mencapai tujuan pembelajaran yang aktif dan menyenangkan. Maka dari itu kita sangat perlu untuk memahami dan mempelajari bagaimana menggunakan media dengan baik dan benar sesuai dengan proses pembelajaran.

Adanya penelitian ini agar kita mengetahui bagaimana perbedaan siswa yang menggunakan media pembelajaran berbasis visual dan siswa yang tidak menggunakan media pembelajaran berbasis visual.Sehingga kita bisa mengoptimalkan pemanfaatan media berbasis visual ini untuk pembelajaran IPS di Madrasah Ibtidaiyah. Serta mengetahui kendala-kendala apa saja dalam pembuatan maupun penggunaan media berbasis visual ini.

\section{METODE}

Penelitian ini dilakukan di MI Darul Mutaallimin Sidoarjo.Sampel penelitian ini diambil sebanyak dua kelas yakni kelas 1 yang mewakili untuk kelas bawah dan kelas 5 mewakili bagian kelas atas di MIDarul Mutaallimin Sidoarjo.Penelitian ini menggunakan metode deskriptif kualitatif dan jenis penelitian ini adalah menggunakan data kualitatif.Metode deskriptif kualitatif adalah metode yang bertujuan untuk mendeskripsikan perilaku orang, peristiwa lapangan, serta kegiatan-kegiatan tertentu secara terperinci.

\footnotetext{
${ }^{13}$ Arsyad, Azhar. Media Pembelajaran. Jakarta: Rajagrafindo Persada. 2013:20
} 
Dalam penelitian ini, peneliti menggunakan dua teknik dalam pengumpulan data yakni, observasi dan wawancara. Observasi yang dilakukan bertujuan untuk mengamati bagaimana perbedaan proses pembelajaran yang menggunakan media berbasis visual dan yang tidak menggunakan media berbasis visual pada pembelajaran IPS, serta pemanfaatan media berbasis visual pada pembelajaran IPS di MIDarul Mutaallimin Sidoarjo .

Wawancara dilakukan untuk mengungkapkan data yang tidak bisa diungkapkan melalui observasi.Peneliti disini melakukan wawancara dengan guru kelas masing-masing yakni guru kelas yang memegang kelas atas dan kelas bawah.Wawancara yang dilakukan dengan mengajukan pertanyaan seputar pemanfaatan dan kendala pada media pembelajaran berbasis visual ini.

\section{HASIL PENELITIAN DAN PEMBAHASAN}

Hasil Hasil dari penelitian kami adalah berdasarkan observasi yang telah dilakukan masih banyak guru atau pendidik yang melakukan proses pembelajaran dengan hanya menggunakan media pembelajaran berbasis visual berupa buku paket, lks, dan papan tulis. Hal itu berakibat pada proses belajar mengajar menjadi monoton dan membuat para peserta didik tidak memiliki semangat untuk belajar karena apa yang mereka lihat dari pagi sampai siang hanya sebuah buku dan papan tulis.

Pada saat wawancara dengan para guru, mereka membenarkan bahwasanya mereka hanya melakukan proses pembelajaran dengan menggunakan media berupa buku paket, lks dan papan tulis saja. Sebenarnya para guru atau pengajar ingin membuat pembelajaran yang menyenangkan dengan menggunakan media berbasis visual yang lebih menarik dan kreatif. Namun, kendala yang dialami adalah faktor keterbatasan waktu, biaya dan faktor usia. Dalam membuat media pembelajaran berbasis visual selain buku paket, lks dan papan tulis, mereka membutuhkan waktu yang cukup lama dan para guru atau pengajar kebanyakan sudah berumah tangga.Jadi, tidak ada waktu untuk membuat media pembelajaran visual yang lebih menarik dan kreatif. 
Pembelajaran IPS di MI Darul Mutaallimin ini kurang mampu menarik perhatian siswa sehingga membuat kegiatan belajar mengajar menjadi kurang maksimal, karena hanya menggunakan media pembelajaran berbasis visual berupa buku paket yang meskipun didalamnya sudah ada gambar-gambar yang menarik.Siswa kelas bawah menunjukkan bahwa mereka masih suka bermain dengan hal-hal yang menyenangkan.Hal ini menjadikan guru atau pendidik seharusnya menyiapkan media pembelajaran yang lebih mampu menarik perhatian siswanya.

Namun, masih disayangkan karena para guru tidak menggunakan media pembelajaran yang lebih kreatif dikarenakan kurangnya pengetahuan tentang cara pembuatan ataupun pemilihan media pembelajaran yang tepat sesuai dengan faktor pendukung pemilihan media, hal ini membuat para pengajar hanya menggunakan media yang berupa menyanyi, bertepuk tangan dan sebagainya tanpa menggunakan media yang berbasis visual yang menarik dan kreatif. Disamping itu mereka berpendapat, ini adalah cara yang efektif dikarenakan untuk pembuatan media sendiri membutuhkan biaya.

Pada siswa kelas atas yakni kelas 5 juga tidak jauh berbeda dari kelas bawah. Akan tetapi disini sudah menggunakan media pembelajaran berbasis visual meskipun hanya media sederhana, disini para guru rata-rata memfokuskan pembelajaran dikarenakan pada peserta didik akan naik ke jenjang kelas 6 sehingga mereka terkadang hanya difokuskan pada buku dan penjelasan dari guru yang secara tidak langsung mereka hanya belajar mengenai teori saja.

Dalam keadaan seperti ini terkadang para pengajar atau peserta didik terkesan menyampingkan akan keberadaan media pembelajaran, yang notabennya media ini digunakan sebagai alat penunjang pembelajaran agar materi dapat tersampaikan ke peserta didik dengan lebih jelas karena tidak semua peserta didik dapat menangkap apa yang guru jelaskan saat berada di dalam kelas. Dalam kasus seperti ini sebaiknya para pengajar atau guru sering mengikuti berbagai latihan tentang kependidikan maupun sering-sering mencari detensi di berbagai media internet tentang bagaimana cara pembelajaran yang mengasikkan bagi siswa. 
Misalnya dengan cara menggunakan media, para pengajar dapat membuat berbagai media pembelajaran dengan baik sesuai kaidah serta faktor yang tepat untuk memilih jenis media tersebut. Diantara faktor yang dapat digunakan untuk membuat media antara lain memperhatikan tujuan dari pembelajaran yang ingin dicapai saat pembelajaran, kecocokan antara materi dan media yang akan digunakan, melihat situasi atau keadaan peserta didik, pengoperasionalan media yang mudah serta biaya yang masih dapa dijangkau oleh pengajar maupun peserta didik.

Perbedaan antara pembelajaran yang belum dengan pembelajaran yang sudah menggunakan media pembelajaran berbasis visual selain buku paket dan papan tulis terlihat jelas. Guru lebih mudah menjelaskan atau menyampaikan materi IPS menggunakan gambar yang menyangkut berbagai masalah di kehidupan masyarakat sekitar dengan didasarkan berbagai ilmu daripada hanya menggunakan gambar penjelasan yang ada di buku paket. Siswa pun juga tampak lebih antusias mengikuti pembelajaran dengan gambar yang menarik selain yang ada di buku paket.Siswa Madrasah Ibtidaiyah adalah siswa yang masih berada pada tahap anak-anak yang membutuhkan pembelajaran yang efektif dan inovatif, yang mampu merangsang keaktifan siswa, merangsang kreatifitas mereka dan meningkatkan prestasi belajar. Sehingga dibutuhkan media yang tepat untuk memaksimalkan proses belajar mereka.

Solusi yang dapat diberikan kepada guru mengenai hal ini adalah tetap sebisa mungkin mengusahakan membuat media pembelajaran berbasis visual mengenai materi yang akan dibawakan. Media visual yang dibuat tidaklah harus yang terlalu memakan banyak waktu dan biaya.Contohnya Bisa dengan menampilkan slide-slide foto/video mengenai materiapabila di sekolah tersebut memiliki LCD proyektor atau bisa juga dengan alat-alat sederhana yang ada pada lingkungan sekolah, media pembelajaran visual yang sederhana juga dapat membantu proses pembelajaran sehingga bisa mencapai tujuan pembelajaran yang aktif dan menyenangkan. 


\section{KESIMPULAN}

Jika ditarik benang merah terkait dengan penelitian pemanfaatan media pembelajaran berbasis visual untuk pembelajaran IPS di MI Darul Mutaallimin Sidoarjo. Maka dapat ditarik kesimpulan sebagai berikut;

Pemanfaatan media pembelajaran dalam mata pelajaran IPS di MI Darul Mutaallimin ini hanya mengoptimalkan adanya buku paket, lks dan papan tulis.hal ini dikarenakan dalam pembuatan media visual yang lebih kreatif dan menarik memerlukan waktu dan biaya.Terdapat perbedaan kecepatan pemahaman antara kelas yang menggunakan dan tidak menggunakan media pembelajaran berbasis visual selain buku paket, lks dan papan tulis. Mereka yang menggunakan media pembelajaran lebih cepat memahami apa yang dijelaskan guru dan guru juga tidak kesulitan untuk menjelaskan materi yang sifatnya khayal. Sehingga dengan adanya media visual selain buku paket dan papan tulis ini, siswa menjadi lebih aktif dan antusias dalam mengikuti pembelajaran.Dan dapat meningkatkan pemahaman siswa dalam belajar.

Dalam hal ini, guru adalah faktor utama dalam pemanfaatan media pembelajaran ini harus mengatur waktunya sedemikian rupa demi menjaga kestabilan siswanya dalam belajar. Apabila siswa mengalami proses belajar mengajar dengan tidak baik, maka siswa tidak akan bersemangat lagi untuk belajar dan mematikan kekreatifan mereka. 


\section{DAFTAR PUSTAKA}

I.A.Ainiya, Pemanfaatan Media Audio Visual Sebagai Sumber Pembelajaran Sejarah.Indonesian Journal of History education, Vol. 3 (1): 2014

A.CArsyad, Media Pembelajaran. Jakarta: Rajagrafindo Persada.2013

M. Fadli, Pengembangan Media Pembelajaran Berbasis Video Kelas IV Sekolah Dasar.Jurnal Dimensi Pendidikan dan Pembelajaran Vol 3. No. 1: 2015

N Jalinus, dan Ambiyar. Media dan Sumber Pembelajaran. (Jakarta: Prena Media Group). 2016

M. Rahmatullah, Pengaruh Pemanfaatan Media Pembelajaran Film Animasi Terhadap Hasil Belajar (Studi Eksperimen pada Mata Pelajaran IPS Siswa Kelas VII SMPN 66 Banjarmasin). Edisi Khusus No. 1

R Cepi, Media Pembelajaran, Jakarta : Direktorat Jendral Pendidikan Islam KEMENAG RI. 2012

Sukiman. Pengembangan Media Pembelajaran. Yogyakarta: Pedagogia, 2012

S. Ahmad, Pengembangan Pembelajaran IPS di Sekolah Dasar, Jakarta : Prenada Media Group. 2014 